IP Periodica Polytechnica Social and Management Sciences

\author{
26(1), pp. 87-101, 2018 \\ https://doi.org/10.3311/PPso.9611 \\ Creative Commons Attribution (i)
}

RESEARCH ARTICLE

\section{Assessing Postgraduate Students' Satisfaction with Quality of Services at a Turkish University Using Alternate Ordered Response Models}

\author{
Ali Kemal Çelik ${ }^{1}$, Erkan Oktay², Üstün Özen ${ }^{3}$, \\ Abdulkerim Karaaslan ${ }^{2}$, İkram Yusuf Yarbaş $1^{4}$ \\ Received 16 June 2016; accepted after revision 12 May 2017
}

\begin{abstract}
The aim of this study is to determine postgraduate students' general satisfaction with the quality of academic services. For this purpose, a written-questionnaire was conducted to 400 graduate students at Atatürk University, Turkey. The dependent variable of the study was the satisfaction level of graduate students which has a natural order. Hence, four different ordered logit models were performed to determine factors that may influence satisfaction levels of graduate students with the quality of academic services. Along with standard ordered logit model, other alternative ordered response models were also performed including generalized ordered logit model, partial constrained generalized ordered logit model, and heterogeneous choice model. Results reveal that a variety of factors are associated with quality of higher education services including age group, tuition fee, undergraduate education, monthly individual income, monthly household income, type of graduate school, current status of postgraduate education, advisor's academic degree, and time elapsed for postgraduate education. The outcome of this study may give a valuable information for decision-makers of higher education institutions and may provide a benchmarking option in terms of past, present and future higher education policies.
\end{abstract}

\section{Keywords}

graduate student, university, satisfaction, ordered response models, quality of service

\footnotetext{
${ }^{1}$ Department of Quantitative Methods, Faculty of Economics and Administrative Sciences, Ardahan University, Ardahan, 75000, Turkey

${ }^{2}$ Department of Econometrics, Faculty of Economics and Administrative Sciences, Atatürk University, Erzurum, 25240, Turkey

${ }^{3}$ Department of Management Information Systems, Faculty of Economics and Administrative Sciences, Atatürk University,

Erzurum, 25240, Turkey

${ }^{4}$ Department of Econometrics, Faculty of Economics and Administrative Sciences, Erzurum Technical University, Erzurum, 25240, Turkey

*Corresponding author, e-mail: alikemalcelik@ardahan.edu.tr
}

\section{Introduction}

Higher educational institutions have been overwhelmingly imposed by rapid modifications due to dynamic local and global developments over the recent decades (de Jager and Gbadamosi, 2013) to survive in the service industry and to meet the gradually increasing role of information and communication revolution (Arambewela and Hall, 2006). In this respect, monitoring the outcomes of teaching and learning experiences have been emerged as one of the major goals for higher educational institutions to deliver effective teaching and learning to their students (Guo, 2010), since a satisfied student is adopted as one of the sources of competitive advantage with various outcomes including student loyalty and retention (Arambewela and Hall, 2009). In fact, meeting students' needs and expectations is commonly adopted as the best way for higher educational institutions to attract and retain quality students (Elliott and Shin, 2002). On the other hand, student loyalty is considered by higher educational institutions as a financial basis for academic activities (Grace and Kim, 2008). Nowadays, higher educational institutions pay a close attention to both the value of their graduates' skills and abilities in the society and students' perceptions on educational experience (Ginsburg, 1991; Munteanu et al., 2010).

Since better understanding and addressing the key sources of student satisfaction is adopted as a challenge for many higher educational institutions (Arambewela and Hall, 2006), a respectable number of studies have emphasized on determining the significant factors that may possibly influence student's level of satisfaction. Gender was found an important contributor of overall student satisfaction. Prior studies found that female students (Aldemir and Gülcan, 2004; de Jager and Gbadamosi, 2013) were relatively more satisfied. Other research (Sojkin et al., 2012) indicated male students were more satisfied than female students. Quality, expertise and effectiveness of academic staff (Aldemir and Gülcan, 2004; Arambewela and Hall, 2008; 2009; Arambewela et al., 2006; Barnes and Randall, 2012; Butt and ur Rehman, 2010; Clemes et al., 2008; Douglas et al., 2006; Gibson, 2010; F. M. Hill, 1995; Y. Hill et al., 2003; Mai, 2005; Negricea et al., 2014; 
Ravindran and Kalpana, 2012; Roman, 2014; Sakthivel et al., 2005; Wang and Tseng, 2011; Wilkins et al., 2013; 2012) were also found to significantly affect student satisfaction with quality of higher education services. Similarly, many earlier studies (de Kleijn et al., 2012; Harman, 2003; Khosravi et al., 2013; Munteanu et al., 2010; Sutton and Sankar, 2011; Zhao et al., 2007) underlined the importance of academic advising services on student satisfaction. Among others, the significant impact of graduate school (Ravindran and Kalpana, 2012; Uysal, 2015), learning resources, use of technology and physical facilities (Arambewela and Hall, 2008; Demaris and Kritsonis, 2008; Munteanu et al., 2010; Petruzzellis et al., 2006; Ravindran and Kalpana, 2012; Wilkins et al, 2013; 2012; Yang, Becerik-Gerber, \& Mino, 2013), course and program effectiveness (Denson et al., 2010; Guo, 2010; Harman, 2003; F. M. Hill, 1995; Marzo Navarro et al., 2005; Montanari and Viroli, 2010; Munteanu et al., 2010; Wilkins et al., 2012), tuition fee (Clemes et al., 2008), university image (Alves and Raposo, 2007; Arambewela and Hall, 2008; Azoury et al., 2014; Brown and Mazzarol, 2009; Clemes et al., 2008; Helgesen and Nesset, 2007), year of study (Clemes et al., 2008; Oldfield and Baron, 2000), student loyalty and retention (Brown and Mazzarol, 2009; DeShields Jr et al., 2005; Elliott and Healy, 2001; Gibson, 2010; Giner and Rillo, 2015; Helgesen and Nesset, 2007; Schertzer and Schertzer, 2004) has taken their respectable place in the existing literature.

Student satisfaction is widely accepted as an influential barometer of the quality of service for higher educational institutions to sustain their competitive advantage (Arambewela and Hall, 2006). Additionally, students' perceived quality of service is strictly associated with student satisfaction unless each of these concepts are measured independently (Athiyaman, 1997). Student satisfaction with higher education services is generally evaluated through methods that concentrates on assessing teaching and learning and methods assessing total student experience (Aldridge and Rowley, 1998). Satisfaction feedback questionnaires are commonly preferred by higher educational institutions to seek students' perceptions on all aspects of academic life (Douglas et al., 2006), as ongoing feedback is a useful way to provide students to comment on potential improvements to the academic program and increased retention (Gibson, 2010). However, education is no longer limited to high school and college experiences since more and more students undertake graduate courses (Wang and Tseng, 2011). Indeed, a number of studies (Arambewela and Hall, 2008; 2009; Arambewela et al., 2006; Barnes and Randall, 2012; de Kleijn et al., 2012; Harman, 2003; Sutton and Sankar, 2011; Uysal, 2015; Wilkins and Stephens Balakrishnan, 2013; Zhao et al., 2007) have successfully concentrated on postgraduate students' expectations and satisfaction. Nevertheless, further research is periodically needed to better understand postgraduate students' level of satisfaction and which indicators contribute to their satisfaction levels for improving the quality of higher education services. The main objective of this paper is to determine major socio-economic and demographic influencers of postgraduate satisfaction at a Turkish university. The remainder of the paper is as the following. Second section reviews the existing literature that addresses student satisfaction in many aspects. Third section describes the materials and methods used in the study. Fourth section introduces the estimation results in detail. The paper concludes with a discussion of results in the lights of future higher education polices.

\section{Materials and methods}

\subsection{Ordered response models}

Ordered categorical variables are frequently used in many social science applications. In principle, these type of variables denote the rank order of a particular attribute whilst such rankings do not necessarily represent the actual magnitudes on a substantive scale (Powers and Xie, 2008). When the outcomes are naturally ordered, the researcher should notice the fact that the dependent variable is considered as both discrete and ordinal. In other words, if the dependent variable has three categories, a linear regression would recognize the difference between category 3 and 2 identically to the difference between category 2 and 1 (Borooah, 2002).

The probability of an observed outcome such as $y=m$ for given values of $x$ 's designates to the region of the distribution where $y^{*}$ between $\tau_{m-1}$ and $\tau_{m}$ as

$$
\operatorname{Pr}(y=m \mid x)=\operatorname{Pr}\left(\tau_{m-1} \leq y^{*}<\tau_{m} \mid x\right)
$$

where $\tau$ 's are thresholds and $y^{*}$ is the latent variable. When $y^{*}$ is substituted with $x \beta+\varepsilon$, Eq. (1) can be rewritten as

$$
\operatorname{Pr}(y=m \mid x)=F\left(\tau_{m}-x \beta\right)-F\left(\tau_{m-1}-x \beta\right)
$$

where $F$ denotes the cumulative function for $\varepsilon$. Further, the ordered models can be developed as a nonlinear probability model without the idea of latent variables. For $m=1, J-1$, the odds that an outcome is then or equal to $m$ versus greater than $m$ given $x$ are as follows:

$$
\Omega_{\leq m \mid>m}(x) \equiv \frac{\operatorname{Pr}(y \leq m \mid x)}{\operatorname{Pr}(y>m \mid x)}
$$

For instance, assuming the logs of the odds is equal

$$
\ln \Omega_{\leq m \mid>m}(x)=\tau_{m}-x \beta
$$

the odds of $m \leq 2$ versus $m>2$ can be computed. For a simple three-category, the odds will be as the following (Long and Freese, 2006):

$$
\begin{aligned}
& \ln \frac{\operatorname{Pr}(y \leq 1 \mid x)}{\operatorname{Pr}(y>1 \mid x)}=\tau_{1}-\beta_{1} x_{1} \\
& \ln \frac{\operatorname{Pr}(y \leq 2 \mid x)}{\operatorname{Pr}(y>2 \mid x)}=\tau_{2}-\beta_{1} x_{1}
\end{aligned}
$$


Generalized ordered logit (GOLOGIT) model can simply be defined as

$$
P\left(Y_{i}>j\right)=g\left(X \beta_{j}\right)=\frac{\exp \left(\alpha_{j}+X_{i} \beta_{j}\right)}{1+\left[\exp \left(\alpha_{j}+X_{i} \beta_{j}\right]\right.}, j=1,2, \ldots, M-1
$$

where $M$ is the number of categories of the ordinal dependent variable. Moreover, the parallel lines model estimated by ordered logit (OLOGIT) model is a special case of the GOLOGIT model that can be written as

$$
P\left(Y_{i}>j\right)=g(X \beta)=\frac{\exp \left(\alpha_{j}+X_{i} \beta_{j}\right)}{1+\left[\exp \left(\alpha_{j}+X_{i} \beta_{j}\right]\right.}
$$

for $j=1,2, \ldots, M-1$. It can be easily noticed that the parallel lines model differs from the standard GOLOGIT model except for the Betas that are the same for all categories. For instance, when there are four categories, first category $(J=1)$ is contrasted with category 2, 3, and 4 (Williams, 2006). Whilst the generalized model is frequently preferred, most researchers disregard the parallel lines assumption that is often violated (Fu, 1999). In that context, to overcome the limitations of parallel lines restrictions, partial proportional odds model is introduced as a special case of GOLOGIT model, whereas some of the Beta coefficients can differ. For instance, Eq. (9) presents a partial proportional odds (PPL) model which enables the Betas for $X 3$ to differ for $j=1,2, \ldots, M-1$ (Williams, 2006):

$$
P\left(Y_{i}>j\right)=\frac{\exp \left(\alpha_{j}+X 1_{i} \beta 1+X 2_{i} \beta 2+X 3_{i} \beta 3_{j}\right)}{1+\left[\exp \left(\alpha_{j}+X 1_{i} \beta 1+X 2_{i} \beta 2+X 3_{i} \beta 3_{j}\right)\right]}
$$

Heterogeneous choice model (HCM) provides the researchers to examine determinants of the conditional variance. For an ordered variable $y$ with $M$ categories, the full heterogeneous choice model can be written as

$$
P\left(y_{i}>m\right)=\operatorname{invlogit}\left\{\frac{\sum_{k} x_{i k} \beta_{k}-\kappa_{m}}{\exp \left(\sum_{j} z_{i j} \gamma_{j}\right)}\right\}=\operatorname{invlogit}\left(\frac{\sum_{k} x_{i k} \beta_{k}-\kappa_{m}}{\sigma_{i}}\right)
$$

for $m=1,2, \ldots, M-1$, where variance equation $\sigma_{i}$ can be defined as

$$
\sigma_{i}=\exp \left(\sum_{j} z_{i j} \gamma_{j}\right)
$$

For any given response, the full heterogeneous choice model in Eq. (10) presents how the choice and variance equations are combined to put forward the probability (Williams, 2010).

Whilst regression parameters yield information about the sensitivity of a dependent variable regarding changes in several independent variables, in some circumstances, it may be more appropriate to measure these sensitivities in terms of percentages, where elasticities are also preferred. However, standard elasticity calculation is not considered as a valid measurement for indicator variables which were defined as dummies (1 for success and 0 for failure). For these types of variables a pseudo-elasticity measure given by

$$
E_{x_{k i}}^{P(i)}=\frac{\exp \left[\Delta\left(\beta_{i} x_{i}\right)\right] \sum_{\forall I} \exp \left(\beta_{k I} x_{k I}\right)}{\exp \left[\Delta\left(\beta_{i} x_{i}\right)\right] \sum_{\forall I} \exp \left(\beta_{k I} x_{k I}\right)+\sum_{\forall I \neq I_{n}} \exp \left(\beta_{k I} x_{k I}\right)}-1
$$

can be used, where $I_{n}$ denotes the set of alternate outcomes with $x_{k}$ in the function determining the outcome, and $I$ denotes the set of all possible outcomes. These elasticities capture the potential effect that a change in a variable determining the likelihood of alternative outcome $i$ has on the probability this outcome will be selected, which are also called as direct elasticities (Washington et al., 2010).

\subsection{Study design, sample and data collection}

This paper aims to determine possible factors that may affect postgraduate student satisfaction with a variety of higher education services. For this purpose, a well-established written questionnaire was conducted among 400 postgraduate students at Atatürk University. The questionnaire involves five sections. First section is comprised of socio-demographic and socio-economic questions about postgraduate students. The following sections include questions several statements about measuring respondents' satisfaction with the quality of various higher education services such as academic advising, physical facilities, academic staff, graduate school, and university image, respectively. Following earlier work (Arambewela and Hall, 2008; 2009; Arambewela et al., 2006), the term 'postgraduate' is defined as students who follow graduate studies up to and including a $\mathrm{PhD}$ degree, excluding post-doctoral students. The minimum sample size for this study was calculated as 363 , where 400 respondents successfully exceed the minimum sample size requirement (see, Yamane (1967) for more information about such a calculation). The questionnaire had a relatively high reliability with Cronbach Alpha value of 0.948 . This study has five separate dependent variables about satisfaction with academic advising services, physical facilities, academic staff, graduate school, and university image. As these dependent variables are naturally ordered, standard and alternative ordered response models including OLOGIT, GOLOGIT, PPL, and HCM were employed for estimation. Some categories of dependent variables were merged due to relatively small frequencies. On the other hand, eleven independent variables were used in the study including gender, marital status, agegroup, tuition fee, undergraduate education, monthly individual and household income, type of graduate school, current status of graduate education, advisor's academic degree, and time elapsed for graduate education in years. 


\section{Results}

\subsection{Descriptive statistics}

Table 1 presents descriptive statistics for both dependent and independent variables used in the study. As shown in Table 1, a majority of the respondents were satisfied or very satisfied with the academic advising $(81.41 \%)$, academic staff (72.77\%), and university image (71.72\%), while almost half of the respondents were satisfied or very satisfied with physical facilities (43.81\%), and graduate school (42.64\%). More than $60 \%$ of the respondents were male $(60.50 \%)$ and a majority of them were single $(71.50 \%)$. More than half of the respondents $(51.92 \%)$ were aged between $25-30$ years and a vast majority of them $(85.00 \%)$ do not currently receive tuition fee from the government. More than $75 \%$ of the respondents (75.50) were studied at Atatürk University during their undergraduate education. More than half of the respondents $(58.01 \%)$ had more than 2000 TL monthly individual income, whereas almost $34 \%$ of them had more than 2500 TL monthly household income. More than $32 \%$ of the respondents $(32.50 \%)$ were studying in applied sciences, while almost half of the respondents were at the master-course stage of their graduate education. Finally, academic advisor's degree for almost $38 \%$ of the respondents $(37.56 \%)$ were assistant professor and more than half of the respondents $(52.75 \%)$ were postgraduate students since more than six years.

The probability of dissatisfaction with academic advising services decreases with respect to low monthly individual income. Accordingly, the probability of very dissatisfaction or dissatisfaction decreases by $123.14 \%$ when postgraduate students had monthly individual income between 500 and 1000 TL. The probability of very dissatisfaction or dissatisfaction also decreases by almost $23 \%$ for postgraduate students who had monthly income between 1001 and 1500 TL and 1501 and 2000 TL. In contrast, the probability of very dissatisfaction or dissatisfaction increases by more than $53 \%$ since monthly household income was between 1501 and 2000 TL.

The probability of very dissatisfaction or dissatisfaction or neutral increases by $39.19 \%$ and $28.67 \%$, respectively for social sciences postgraduate students. A similar result was found for education sciences postgraduate students where the probability of very dissatisfaction or dissatisfaction increases by $51.40 \%$. Estimation results revealed that the probability of very dissatisfaction or dissatisfaction with academic advising services increases by $90.39 \%$ when academic advisor's degree was assistant professor for PPL model. Similarly, the probability of very dissatisfaction or dissatisfaction increases by $82.63 \%$ since time elapsed for postgraduate education was less than two years. This probability also increases by more than $15 \%$ when time elapsed for postgraduate education was between 2 and 4 years.

Estimation results for HCM indicates that when undergraduate education was successfully accomplished at Atatürk University, the probability of very dissatisfaction or dissatisfaction increased by $65.84 \%$. The probability of very dissatisfaction or dissatisfaction decreases by almost $50 \%$ for relatively low monthly individual income postgraduate students. On the contrary, this probability increases by almost 53\% for relatively high monthly individual income respondents. Similarly, the probability of very dissatisfaction or dissatisfaction increases by nearly $19 \%$ when the respondents have monthly household income between 1501 and 2000 TL. Again, social sciences postgraduate students were more dissatisfied group where the probability of very dissatisfaction or dissatisfaction increases by almost $42 \%$. Finally, the probability of very dissatisfaction or dissatisfaction also increases by almost $35.41 \%$ when time elapsed for postgraduate education was less than two years.

Table 4 indicates estimation results along with their relevant average pseudo-direct elasticities of OLOGIT model for satisfaction with academic staff. As OLOGIT model does not violate parallel lines assumption proposed by Brant (1990), other alternative ordered response models were not necessarily estimated. The OLOGIT model fits well with statistically acceptable significance level at $95 \%$ confidence level or above. The interpretation of the corresponding model was performed using average direct pseudo-elasticities. Accordingly, the probability of very dissatisfaction or dissatisfaction of postgraduate students with academic staff decreases by $22.12 \%$ when their monthly individual income was between 500 and 1000 TL. Similar to PPL and HCM for academic advising services, social sciences postgraduate students declared their dissatisfaction with academic staff. Particularly, the probability of very dissatisfaction or dissatisfaction of social sciences students increases by almost 55\%. One noteworthy result was about the dissatisfaction of applied sciences students with academic staff, while the probability of very dissatisfaction or dissatisfaction increases by almost $74 \%$.

Estimation results of OLOGIT model in Table 4 revealed that current status of postgraduate education is associated with the level of satisfaction with academic staff. Accordingly, the probability of very dissatisfaction or dissatisfaction of postgraduate students who are at $\mathrm{PhD}$ course level of their postgraduate education increases by $20.3 \%$. Finally, advisor's academic degree was another statistically significant factor for the level of satisfaction with academic staff and the probability of very dissatisfaction or dissatisfaction decreases by almost $42 \%$.

Estimation results indicated that satisfaction with graduate school were associated with a variety factors for statistically significant GOLOGIT and PPL models as shown in Table 5. Since fitted OLOGIT model violates the parallel lines assumption alternative ordered response models were fitted. The interpretation of the relevant models were performed using average direct pseudo-elasticities presented in Table 6. As indicated in Table 6 , the probability of moderate satisfaction increases by almost $55 \%$ when postgraduate students were younger than 25 years. In contrast, the probability of very dissatisfaction or dissatisfaction substantially decreases by almost $70 \%$ for age group between 
Table 1 Descriptive statistics of variables

\begin{tabular}{|c|c|c|c|}
\hline Variables & Frequency $(\%)$ & Variables & Frequency $(\%)$ \\
\hline Satisfaction with the advising & & Monthly individual income & \\
\hline Very dissatisfied/dissatisfied & $36(9.05)$ & Less than $500 \mathrm{TL}^{*}$ & $47(12.98)$ \\
\hline Neutral & $38(9.55)$ & $500-1000 \mathrm{TL}$ & $72(19.89)$ \\
\hline Satisfied/very satisfied ${ }^{*}$ & $324(81.41)$ & $1001-1500 \mathrm{TL}$ & $17(4.70)$ \\
\hline Satisfaction with physical facilities & & $1501-2000 \mathrm{TL}$ & $16(4.42)$ \\
\hline Very dissatisfied/dissatisfied & $118(30.41)$ & More than $2000 \mathrm{TL}$ & $210(58.01)$ \\
\hline Neutral & $100(25.77)$ & Monthly household income & \\
\hline Satisfied/very satisfied ${ }^{*}$ & $170(43.81)$ & Less than $1000 \mathrm{TL}^{*}$ & $14(4.31)$ \\
\hline Satisfaction with academic staff & & $1000-1500 \mathrm{TL}$ & $66(20.31)$ \\
\hline Very dissatisfied/dissatisfied & $36(9.16)$ & $1501-2000 \mathrm{TL}$ & $67(20.62)$ \\
\hline Neutral & $71(18.07)$ & $2001-2500 \mathrm{TL}$ & $67(20.62)$ \\
\hline Satisfied/very satisfied ${ }^{*}$ & $286(72.77)$ & More than $2500 \mathrm{TL}$ & $111(34.15)$ \\
\hline Satisfaction with graduate school & & Graduate school & \\
\hline Very dissatisfied/dissatisfied & $109(27.66)$ & Health sciences* & $61(15.25)$ \\
\hline Neutral & $117(29.70)$ & Social sciences & $129(32.25)$ \\
\hline Satisfied/very satisfied ${ }^{*}$ & $168(42.64)$ & Applied sciences & $130(32.50)$ \\
\hline Proud of university image & & Educational sciences & $80(20.00)$ \\
\hline Definitely disagree/disagree & $46(11.62)$ & Current status of graduate ed. & \\
\hline Neutral & $66(16.67)$ & Master-course & $186(46.50)$ \\
\hline Agree/definitely agree ${ }^{*}$ & $284(71.72)$ & Master-thesis & $72(18.00)$ \\
\hline Gender & & PhD-course & $62(15.50)$ \\
\hline Female & $158(39.50)$ & PhD-qualification* & $23(5.75)$ \\
\hline Male* $^{*}$ & $242(60.50)$ & $\mathrm{PhD}$-thesis & $57(14.25)$ \\
\hline Marital status & & Advisor's academic degree & \\
\hline Married & $114(28.50)$ & Assistant professor & $148(37.56)$ \\
\hline Single* & $286(71.50)$ & Associate professor & $146(37.06)$ \\
\hline Age group & & Full professor ${ }^{*}$ & $100(25.38)$ \\
\hline Younger than 25 years & $109(27.88)$ & Time elapsed (in years) & \\
\hline $25-30$ years & $203(51.92)$ & Two years and less & $48(13.19)$ \\
\hline Elder than 30 years ${ }^{*}$ & $79(20.20)$ & $3-4$ years & $73(20.05)$ \\
\hline Tuition fee & & $5-6$ years & $51(14.01)$ \\
\hline Yes & $60(15.00)$ & More than 6 years* & $192(52.75)$ \\
\hline $\mathrm{No}^{*}$ & $340(85.00)$ & & \\
\hline \multicolumn{4}{|l|}{ Undergraduate education } \\
\hline Atatürk University & $302(75.50)$ & & \\
\hline Other university* & $98(24.50)$ & & \\
\hline
\end{tabular}

Note: TL denotes Turkish Lira; several variables do not have the initial number of sample size due to missing values; ${ }^{*}$ denotes the reference category. 
Table 2 Estimation results of PPL and HCM models for satisfaction with the academic advisor

\begin{tabular}{|c|c|}
\hline Independent variables & Coefficient \\
\hline \multicolumn{2}{|l|}{$P P L$, Coefficient not varying } \\
\hline Graduate school; social sciences & -1.432 \\
\hline Time elapsed (in years); $3-4$ years & -0.810 \\
\hline \multicolumn{2}{|l|}{ PPL, Threshold 1 and 2} \\
\hline Age group; younger than 25 years & 2.763 \\
\hline Age group; 25 - 30 years & 2.849 \\
\hline Tuition fee; yes & -3.397 \\
\hline Monthly individual income; $500-1000$ TL & 5.804 \\
\hline Monthly individual income; $1001-1500 \mathrm{TL}$ & 4.240 \\
\hline Monthly individual income; $1501-2000 \mathrm{TL}$ & 7.241 \\
\hline Monthly household income; $1501-2000 \mathrm{TL}$ & -2.780 \\
\hline Time elapsed (in years); less than two years & -7.102 \\
\hline Constant & 6.296 \\
\hline \multicolumn{2}{|l|}{ PPL, Threshold 2 and 3} \\
\hline Monthly individual income; $500-1000$ TL & 1.654 \\
\hline Monthly individual income; 1501 - $2000 \mathrm{TL}$ & -1.831 \\
\hline Constant & 5.168 \\
\hline LR Chi-square & 73.69 \\
\hline Pseudo-R & 0.2468 \\
\hline Log-likelihood (full model) & -112.423 \\
\hline AIC & 302.860 \\
\hline $\mathrm{BIC}$ & 444.196 \\
\hline \multicolumn{2}{|c|}{ HCM, Factor affecting the ordinal categorical choice } \\
\hline Graduate school; social sciences & -1.135 \\
\hline \multicolumn{2}{|l|}{ HCM, Factor affecting the error variance } \\
\hline Time elapsed (in years); less than two years & 0.857 \\
\hline Cut point 1 & -4.639 \\
\hline Cut point 2 & -3.833 \\
\hline LR Chi-square & 52.85 \\
\hline Pseudo-R & 0.177 \\
\hline Log-likelihood (full model) & -122.853 \\
\hline AIC & 301.705 \\
\hline $\mathrm{BIC}$ & 403.178 \\
\hline
\end{tabular}

25 and 30 years. However, the probability of moderation satisfaction increases again by almost $70 \%$ for the corresponding age group. According to GOLOGIT model estimation results for satisfaction with graduate school services, monthly individual income was found as statistically significant. The probability of moderate satisfaction with graduate school services increases by almost 10\% when respondents' monthly individual income was between 1001 and 1500 TL. The same probability also increases by $37 \%$ for monthly household income between 1501 and 2000 TL. On the other hand, the probability of very satisfaction or satisfaction of postgraduate students with graduate school services decreases by $26 \%$ for the same monthly income level.

Results indicated that the probability of moderate satisfaction of social sciences students with graduate school services decreases by almost $37 \%$. The analogous probability also decreases by almost $49 \%$ for educational sciences postgraduate students. Another noteworthy result was the association between the levels of satisfaction with graduate school services and current status of graduate education for GOLOGIT model. Specifically, the probability of very satisfaction or satisfaction decreases by almost $52 \%, 17 \%, 15 \%$, and $16 \%$ when they are at the stages of master-course, master-thesis, $\mathrm{PhD}$-course, and $\mathrm{PhD}$ thesis, respectively. Time elapsed for postgraduate education was another significant factor, while the probability of moderate satisfaction decreases by almost $11 \%$ when the time elapsed for the education was less than two years. On the contrary, the same probability increases by almost $10 \%$ when the time elapsed for postgraduate education was between four and six years.

Estimation results for PPL model indicated that the probability of very dissatisfaction or dissatisfaction decreases by $5 \%$ for the monthly individual income between 1501 and 2000 TL. On the other hand, this probability increases by almost $15 \%$ for monthly household income between 1501 and 2000 TL. The same probability also increases by almost $26 \%$ for more than 2500 TL monthly household income. Not surprisingly, type of graduate school is associated with the levels of satisfaction with graduate school services. Particularly, social and educational sciences students declared their dissatisfaction. The probability of very dissatisfaction or dissatisfaction increases by almost $17 \%$ and $25 \%$ for social and education sciences postgraduate students, respectively for PPL model. Current status of postgraduate education was also associated with the levels of satisfaction with graduate school services. The probability of very dissatisfaction or dissatisfaction increases by almost 59\%,22\% and $15 \%$ for postgraduate students who were at master-course, master-thesis, and $\mathrm{PhD}$-course stages of their education.

Table 7 presents estimation results for GOLOGIT and PPL models for postgraduate students' satisfaction with physical facilities. Since OLOGIT model violates the parallel line assumption, alternative ordered response models were fitted and GOLOGIT and PPL models were found as statistically sound. The interpretation of both models would be performed using the average direct pseudo-elasticities in Table 8. As shown in Table 8 , the probability of moderate satisfaction with physical facilities decreases by $29 \%$ when postgraduate students receive tuition fee for their education. On the other hand, when monthly individual income was between 1001 and 1500 TL, the probability of very satisfaction or satisfaction decreases by almost $7 \%$. Type of graduate school was also statistically 
Table 3 Pseudo-elasticities of PPL and HCM models for satisfaction with the academic advising services

\begin{tabular}{|c|c|c|c|}
\hline Independent variables & Category 1 & Category 2 & Category 3 \\
\hline \multicolumn{4}{|l|}{ PPL Model } \\
\hline Age group; younger than 25 years & $-74.70 \%$ & & \\
\hline Age group; $25-30$ years & $-135.52 \%$ & & \\
\hline Tuition fee; yes & $59.29 \%$ & & \\
\hline Monthly individual income; $500-1000 \mathrm{TL}$ & $-123.14 \%$ & & $2.98 \%$ \\
\hline Monthly individual income; $1001-1500 \mathrm{TL}$ & $-23.22 \%$ & & \\
\hline Monthly individual income; $1501-2000 \mathrm{TL}$ & $-22.30 \%$ & & \\
\hline Monthly household income; $1501-2000 \mathrm{TL}$ & $53.28 \%$ & & \\
\hline Graduate school; social sciences & $39.19 \%$ & $28.67 \%$ & $-3.33 \%$ \\
\hline Graduate school; educational sciences & $51.40 \%$ & & \\
\hline Advisor's academic degree; assistant professor & $90.39 \%$ & & \\
\hline Time elapsed (in years); less than two years & $82.63 \%$ & & \\
\hline Time elapsed (in years) $; 2-4$ years & $15.52 \%$ & $14.20 \%$ & $-1.31 \%$ \\
\hline \multicolumn{4}{|l|}{$H C M$} \\
\hline Undergraduate education; Atatürk University & $65.84 \%$ & $60.27 \%$ & $-5.57 \%$ \\
\hline Monthly individual income; $500-1000 \mathrm{TL}$ & $-50.31 \%$ & $-46.05 \%$ & $4.26 \%$ \\
\hline Monthly individual income; more than $2000 \mathrm{TL}$ & $52.93 \%$ & $48.46 \%$ & $-4.48 \%$ \\
\hline Monthly household income; $1501-2000 \mathrm{TL}$ & $19.12 \%$ & $17.50 \%$ & $-1.62 \%$ \\
\hline Graduate school; social sciences & $41.64 \%$ & $38.12 \%$ & $-3.52 \%$ \\
\hline Time elapsed (in years); less than two years & $35.41 \%$ & $16.29 \%$ & $-2.08 \%$ \\
\hline
\end{tabular}

Table 4 Estimation results and pseudo-elasticities of OLOGIT model for satisfaction with academic staff

\begin{tabular}{lllll}
\hline Independent variables & Coefficient & Category 1 & Category 2 & Category 3 \\
\hline Monthly individual income; 500 - 1000 TL & 1.039 & $-22.12 \%$ & & $4.62 \%$ \\
Graduate school; social sciences & & $54.90 \%$ & $43.38 \%$ & $-11.48 \%$ \\
Graduate school; applied sciences & -2.346 & $73.69 \%$ & $58.27 \%$ & $-15.42 \%$ \\
Current status of graduate ed.; PhD-course & & $20.33 \%$ & $16.08 \%$ & $-4.26 \%$ \\
Advisor's academic degree; assistant professor & 1.163 & $-41.42 \%$ & $-32.76 \%$ & $8.67 \%$ \\
Cut point 1 & -4.813 & & & \\
Cut point 2 & -3.273 & & & \\
Log-likelihood (full model) & -171.744 & & & \\
LR Chi-square & 50.99 & & \\
Pseudo-R & & & \\
AIC & 0.1293 & & \\
BIC & 399.488 & & \\
\hline
\end{tabular}

associated with the levels of satisfaction with physical facilities. The probability of very dissatisfaction or dissatisfaction increases by almost $23 \%$ and decreases by almost $34 \%$ for social and educational sciences postgraduate students. Current status of postgraduate education was found as another significant factor. The probability of moderate satisfaction increases by almost $80 \%, 24 \%$, and $31 \%$ for postgraduate students who were at master-course, master-thesis, and $\mathrm{PhD}$ thesis stages, respectively. The same probability also decreases by almost
$21 \%$ and $11 \%$ when advisor's academic degree was associate professor and the time elapsed for postgraduate education was less than two years, respectively for GOLOGIT model.

PPL model estimates for the levels of satisfaction with physical facilities underline the impact of six significant factors. The relevant estimation results revealed that the probability of moderate satisfaction with physical facilities decreases by almost $20 \%$ when postgraduate students receive tuition fee from the Turkish government. Age group was another significant 
Table 5 Estimation results of GOLOGIT and PPL models for satisfaction with graduate school

\begin{tabular}{|c|c|}
\hline Independent variables & Coefficient \\
\hline \multicolumn{2}{|l|}{ GOLOGIT, Threshold 1 and 2} \\
\hline Age group; younger than 25 years & 1.791 \\
\hline Age group; $25-30$ years & 2.578 \\
\hline Monthly individual income; $1001-1500 \mathrm{TL}$ & -1.251 \\
\hline Monthly individual income; $1501-2000 \mathrm{TL}$ & -2.447 \\
\hline Graduate school; social sciences & 1.768 \\
\hline Graduate school; educational sciences & 1.884 \\
\hline \multicolumn{2}{|l|}{ GOLOGIT, Threshold 2 and 3} \\
\hline Monthly household income; $1500-2000 \mathrm{TL}$ & -1.316 \\
\hline Monthly household income; more than $2500 \mathrm{TL}$ & -1.398 \\
\hline Current status of graduate education; master-course & -2.074 \\
\hline Current status of graduate education; master-thesis & -1.969 \\
\hline Current status of graduate education; PhD-course & -1.995 \\
\hline Current status of graduate education; $\mathrm{PhD}$-thesis & -1.654 \\
\hline Constant & 3.468 \\
\hline Log-likelihood (full model) & -246.927 \\
\hline LR Chi-square & 92.54 \\
\hline Pseudo- $\mathrm{R}^{2}$ & 0.1578 \\
\hline AIC & 601.854 \\
\hline BIC & 796.766 \\
\hline \multicolumn{2}{|l|}{ PPL, Coefficient not varying } \\
\hline Current status of graduate education; master-course & -1.667 \\
\hline Current status of graduate education; master-thesis & -1.748 \\
\hline Current status of graduate education; PhD-course & -1.424 \\
\hline \multicolumn{2}{|l|}{ PPL, Threshold 1 and 2} \\
\hline Monthly individual income; $1501-2000 \mathrm{TL}$ & 2.004 \\
\hline Graduate school; social sciences & -0.791 \\
\hline Graduate school; educational sciences & -1.588 \\
\hline Constant & 3.215 \\
\hline \multicolumn{2}{|l|}{ PPL, Threshold 2 and 3} \\
\hline Monthly household income; more than $2500 \mathrm{TL}$ & -1.211 \\
\hline Log-likelihood (full model) & -263.447 \\
\hline LR Chi-square & 59.5 \\
\hline Pseudo- $\mathrm{R}^{2}$ & 0.1015 \\
\hline AIC & 592.895 \\
\hline BIC & 712.007 \\
\hline
\end{tabular}


Table 6 Pseudo-elasticities of GOLOGIT and PPL models for satisfaction with graduate school services

\begin{tabular}{|c|c|c|c|}
\hline Independent variables & Category 1 & Category 2 & Category 3 \\
\hline \multicolumn{4}{|l|}{ GOLOGIT } \\
\hline Age group; younger than 25 years & $-37.58 \%$ & $55.15 \%$ & \\
\hline Age group; $25-30$ years & $-70.32 \%$ & $69.31 \%$ & \\
\hline Monthly individual income; $1001-1500 \mathrm{TL}$ & $-7.81 \%$ & $9.65 \%$ & \\
\hline Monthly individual income; $1501-2000 \mathrm{TL}$ & $-6.32 \%$ & $8.71 \%$ & \\
\hline Monthly household income; $1501-2000 \mathrm{TL}$ & & $36.58 \%$ & $-14.07 \%$ \\
\hline Monthly household income; more than $2500 \mathrm{TL}$ & & & $-26.08 \%$ \\
\hline Graduate school; social sciences & $26.93 \%$ & $-36.85 \%$ & \\
\hline Graduate school; educational sciences & $38.00 \%$ & $-49.15 \%$ & \\
\hline Current status of graduate education; master-course & & $61.35 \%$ & $-51.60 \%$ \\
\hline Current status of graduate education; master-thesis & & $25.24 \%$ & $-17.22 \%$ \\
\hline Current status of graduate education; $\mathrm{PhD}$-course & & $34.49 \%$ & $-14.35 \%$ \\
\hline Current status of graduate education; PhD-thesis & & & $-15.44 \%$ \\
\hline Time elapsed (in years); less than two years & & $-10.89 \%$ & \\
\hline Time elapsed (in years); $4-6$ years & & $9.48 \%$ & \\
\hline \multicolumn{4}{|l|}{$P P L$} \\
\hline Monthly individual income; $1501-2000 \mathrm{TL}$ & $-4.98 \%$ & & \\
\hline Monthly household income; $1501-2000 \mathrm{TL}$ & & $14.27 \%$ & \\
\hline Monthly household income; more than $2500 \mathrm{TL}$ & & $25.75 \%$ & $-23.83 \%$ \\
\hline Graduate school; social sciences & $17.24 \%$ & $-23.35 \%$ & \\
\hline Graduate school; educational sciences & $24.98 \%$ & $-24.15 \%$ & \\
\hline Current status of graduate education; master-course & $58.86 \%$ & $15.16 \%$ & $-43.70 \%$ \\
\hline Current status of graduate education; master-thesis & $21.72 \%$ & $5.59 \%$ & $-16.12 \%$ \\
\hline Current status of graduate education; $\mathrm{PhD}$-course & $14.54 \%$ & $3.74 \%$ & $-10.79 \%$ \\
\hline
\end{tabular}

factor increasing the probability of very dissatisfaction or dissatisfaction. Particularly, such probability increases by almost $27 \%$ and $40 \%$ since postgraduate students were younger than 25 years and aged between 25 - 30 years, respectively. The probability of moderate satisfaction decreases by almost $39 \%$ and $19 \%$ when postgraduate students have more than $2000 \mathrm{TL}$ monthly individual income and monthly household income between 2000 and 2500 TL, respectively. The impact of type of graduate school on the level of satisfaction revisits when the probability of very dissatisfaction or satisfaction increases by almost $25 \%$ and decreases by almost $24 \%$ for social and educational sciences postgraduate students, respectively. Finally, the probability of moderate satisfaction with physical facilities increases by $23 \%$ for postgraduate students who were at the master-course stage.

The last model was fitted for postgraduate students' agreement or disagreement with the statements for university image. Since OLOGIT model does not violate the parallel lines assumption, other alternative ordered response models were not necessarily fitted. The model was fitted well at 95\% confidence level or above. Table 9 presents both the estimation and average direct pseudo-elasticity results for the fitted OLOGIT model. The interpretation of the corresponding model was performed using average direct pseudo-elasticities. In Table 9, category 1 denotes the very disagreement or disagreement, category 2 denotes neutral agreement and category 3 denotes the very agreement or agreement levels. Accordingly, the probability of very disagree or disagree category increases by almost $17 \%$ for married postgraduate students. The same probability decreases by almost $47 \%$ and $23 \%$ for postgraduate students who have finished their undergraduate students at Ataturk University and when their monthly individual income was between 500 and 1000 TL, respectively. Finally, type of graduate school was also found as a statistically significant factor. The probability of very disagree or disagree level increases by $28 \%$ and $22 \%$ for applied and educational sciences postgraduate students, respectively. 
Table 7 Estimation results of GOLOGIT and PPL models for satisfaction with physical facilities

\begin{tabular}{ll}
\hline Independent variables & Coefficient \\
\hline GOLOGIT, Threshold 1 and 2 & \\
\hline Tuition fee; yes & -0.952 \\
Graduate school; social sciences & -1.093 \\
Graduate school; educational sciences & 2.115 \\
\hline GOLOGIT, Threshold 2 and 3 & \\
\hline Tuition fee; yes & 1.168 \\
Monthly individual income; 1001 - 1500 TL & -1.987 \\
Graduate school; social sciences & -1.073 \\
Current status of graduate education; PhD-thesis & -1.799 \\
Log-likelihood (full model) & -236.468 \\
LR Chi-square & 100.59 \\
Pseudo-R ${ }^{2}$ & 0.1754 \\
AIC & 580.937 \\
\hline
\end{tabular}

PPL, Coefficients not varying

Graduate school; social sciences

$-1.191$

PPL, Threshold 1 and 2

\begin{tabular}{ll} 
Age group; younger than 25 years & -1.275 \\
Age group; 25 - 30 years & -1.024 \\
Graduate school; educational sciences & 1.450 \\
\hline PPL, Threshold 2 and 3 & 0.857 \\
\hline Tuition fee; yes & -243.856 \\
Log-likelihood (full model) & 85.81 \\
LR Chi-square & 0.1496 \\
Pseudo-R & 557.712 \\
AIC & 683.397 \\
BIC &
\end{tabular}

HCM, Factor affecting the ordinal categorical choice

\begin{tabular}{ll} 
Monthly household income; $1501-2000 \mathrm{TL}$ & 0.574 \\
Graduate school; social sciences & -1.208 \\
\hline HCM, Factor affecting the error variance & 1.168 \\
\hline Tuition fee; yes & -1.227 \\
Graduate school; educational sciences & -0.767 \\
Advisor's academic degree; assistant professor & -252.464 \\
Log-likelihood (full model) & 68.6 \\
LR Chi-square & 0.1196 \\
Pseudo-R & \\
AIC & 560.927 \\
BIC & 661.475 \\
\hline
\end{tabular}

\section{Conclusion}

Student satisfaction is commonly included as one of the major missions of higher educational institutions since students are perceived as a potential customer of higher education services. However, student satisfaction evaluation is a complex concept which cannot be limited to undergraduate students' satisfaction. Whilst some past research addresses the expectations and needs of postgraduate students, periodical future studies are always beneficial for monitoring past and future higher education policies to attract quality postgraduate students and to survive in such a marketing environment with relatively high competition among higher education institutions. This paper mainly aims to determine factors affecting student satisfaction in many aspects with a particular focus on postgraduate students at a well-established university in Turkey. Due to the nature of the dependent variable, four alternative ordered response models were used including OLOGIT, GOLOGIT, PPL and HCM.

Estimation results reveal that several factors are associated with the various quality of higher education services, including age-group, tuition fee, undergraduate education, monthly individual income, monthly household income, type of graduate school, current status of postgraduate education, advisor's academic degree, and time elapsed for postgraduate education. At that point, the results of this study is consistent with many earlier studies (i.e. (Arambewela and Hall, 2008; 2009; Harman, 2003; Munteanu et al., 2010) in the existing literature. Further higher education policies may successfully capture most of these factors and concentrate on the reasons of disagreement levels. For instance, the number of postgraduate students of Atatürk University is gradually increasing. In this sense, further improved policies that emphasizes the orientation of new postgraduate students since younger aged students claimed their dissatisfaction. Particular further policies may be associated with student satisfaction in terms of the type of graduate school. Possible collaboration of higher education managers of all graduate schools may be beneficial to improve the current standards and to sustain the future high satisfaction. Future encouragement of academic staff for their promotion with convenient financial incentives may increase the opportunities of students to work with a more experienced academic staff and may co-ordinately improve the quality of academic outcome. As more satisfied postgraduate students have more chance of being a future qualified academic staff for higher educational institutions, more attention may be paid to keep the time elapsed for postgraduate education at optimal levels. Physical facilities and the quality of services for graduate schools may be especially improved to have a competitive advantage. This study has some limitations. The study was carried out in a specific sample and limited time-period. Future similar studies that emphasize postgraduate student satisfaction periodically and increased sample size may provide 
Table 8 Pseudo-elasticities of GOLOGIT and PPL models for satisfaction with physical facilities

\begin{tabular}{llll}
\hline Independent variables & Category 1 & Category 2 & Category 3 \\
\hline GOLOGIT & & & \\
\hline Tuition fee; yes & & $-29.00 \%$ & $12.22 \%$ \\
Monthly individual income; 1001 - 1500 TL & $8.08 \%$ & $-6.52 \%$ \\
Graduate school; social sciences & $23.11 \%$ & & $-16.49 \%$ \\
Graduate school; educational sciences & $-33.40 \%$ & $36.08 \%$ & \\
Current status of graduate education; master-course & & $80.25 \%$ & \\
Current status of graduate education; master-thesis & & $24.11 \%$ & \\
Current status of graduate education; PhD-thesis & & $31.15 \%$ & $-17.34 \%$ \\
Advisor's academic degree; associate professor & & $-21.29 \%$ & \\
Time elapsed (in years); less than two years & & $-10.70 \%$ & \\
\hline PPL & & & \\
\hline Tuition fee; yes & & $-20.11 \%$ & $9.09 \%$ \\
Age group; younger than 25 years & & $-23.83 \%$ & \\
Age group; 25 - 30 years & $27.22 \%$ & $-41.36 \%$ & \\
Monthly individual income; more than 2000 TL & $39.92 \%$ & $-39.23 \%$ & \\
Monthly household income; 2000 - 2500 TL & & $-18.76 \%$ & \\
Graduate school; social sciences & & $23.84 \%$ & \\
Graduate school; educational sciences & & $23.76 \%$ & \\
Current status of graduate education; master-course & & & \\
\hline & & & \\
\hline
\end{tabular}

Table 9 Estimation results and pseudo-elasticities of OLOGIT model for proud of university image

\begin{tabular}{lllll}
\hline Independent variables & Coefficient & Category 1 & Category 2 & Category 3 \\
\hline Marital status; married & -0.636 & $16.62 \%$ & $11.82 \%$ & $-4.81 \%$ \\
Undergraduate education; Atatürk University & 0.673 & $-47.39 \%$ & $-33.69 \%$ & $13.70 \%$ \\
Monthly individual income; $500-1000 \mathrm{TL}$ & -1.112 & $22.42 \%$ & $15.94 \%$ & $-6.48 \%$ \\
Monthly individual income; $1501-2000 \mathrm{TL}$ & -2.101 & $6.25 \%$ & $4.44 \%$ & $-1.81 \%$ \\
Graduate school; applied sciences & -0.916 & $27.27 \%$ & $19.39 \%$ & $-7.88 \%$ \\
Graduate school; educational sciences & -1.138 & $21.44 \%$ & $15.24 \%$ & $-6.20 \%$ \\
Cut point 1 & -2.954 & & & \\
Cut point 2 & -1.724 & & & \\
Log-likelihood (full model) & -201.682 & & & \\
LR Chi-square & 36.02 & & & \\
Pseudo-R & & & \\
AIC & 0.082 & & \\
BIC & 459.363 & & & \\
\hline
\end{tabular}


a benchmarking option for all authorities of higher education services. Other statistical methods may also be performed to determine the parsimonious model that best measures student satisfaction.

\section{Acknowledgement}

This paper is a revised and extended version of the conference paper included in the "6th Annual Convention of Eurasian Silk Road Universities Consortium (ESRUC), October 1-4, 2015, Casablanca, Morocco"

\section{References}

Aldemir, C., Gülcan, Y. (2004). Student satisfaction in higher education: A Turkish case. Higher Education Management and Policy. 16(2), pp. 109-122. https://doi.org/10.1787/hemp-v16-art19-en

Aldridge, S., Rowley, J. (1998). Measuring customer satisfaction in higher education. Quality Assurance in Education. 6(4), pp. 197-204. https://doi.org/10.1108/09684889810242182

Alves, H., Raposo, M. (2007). Conceptual model of student satisfaction in higher education. Total Quality Management. 18(5), pp. 571-588. https://doi.org/10.1080/14783360601074315

Arambewela, R., Hall, J. (2006). A comparative analysis of international education satisfaction using SERVQUAL. Journal of Services Research. 6(Special), pp. 141-163. [Online]. Available from: https://dro.deakin. edu.au/eserv/DU:30003511/arambewela-comparativeanalysisof-2006. pdf [Accessed: 11th May 2017]

Arambewela, R., Hall, J. (2008). A model of student satisfaction: International postgraduate students from Asia. In E-European Advances in Consumer Research. ((Borghini, S., Grath, M. A., Duluth, C. O. (eds.)). pp. 129-135. [Online]. Available from: http://www.acrwebsite.org/volumes/13925/eacr/vol8/E-08 [Accessed: 11th May 2017]

Arambewela, R., Hall, J. (2009). An empirical model of international student satisfaction. Asia Pacific Journal of Marketing and Logistics. 21(4), pp. 555-569. https://doi.org/10.1108/13555850910997599

Arambewela, R., Hall, J., Zuhair, S. (2006). Postgraduate international students from Asia: Factors influencing satisfaction. Journal of Marketing for Higher Education. 15(2), pp. 105-127. https://doi.org/10.1300/J050v15n02_05

Athiyaman, A. (1997). Linking student satisfaction and service quality perceptions: the case of university education. European Journal of Marketing. 31(7), pp. 528-540. https://doi.org/10.1108/03090569710176655

Azoury, N., Daou, L., Khoury, C. E. (2014). University image and its relationship to student satisfaction-case of the Middle Eastern private business schools. International Strategic Management Review. 2(1), pp. 1-8. https://doi.org/10.1016/j.ism.2014.07.001

Barnes, B. J., Randall, J. (2012). Doctoral student satisfaction: An examination of disciplinary, enrollment, and institutional differences. Research in Higher Education. 53(1), pp. 47-75. https://doi.org/10.1007/s11162-011-9225-4

Borooah, V. K. (2002). Logit and Probit: Ordered and Multinomial Models. SAGE Publications.

Brant, R. (1990). Assessing proportionality in the proportional odds model for ordinal logistic regression. Biometrics. 46(4), pp. 1171-1178. https://doi.org/10.2307/2532457

Brown, R. M., Mazzarol, T. W. (2009). The importance of institutional image to student satisfaction and loyalty within higher education. Higher Education, 58(1), 81-95. https://doi.org/10.1007/s10734-008-9183-8
Butt, B. Z., ur Rehman, K. (2010). A study examining the students satisfaction in higher education. Procedia-Social and Behavioral Sciences. 2(2), pp. 5446-5450.

https://doi.org/10.1016/j.sbspro.2010.03.888

Clemes, M. D., Gan, C. E., Kao, T.-H. (2008). University student satisfaction: An empirical analysis. Journal of Marketing for Higher Education. 17(2), pp. 292-325.

https://doi.org/10.1080/08841240801912831

de Jager, J., Gbadamosi, G. (2013). Predicting students' satisfaction through service quality in higher education. The International Journal of Management Education. 11(3), pp. 107-118. https://doi.org/10.1016/j.ijme.2013.09.001

de Kleijn, R. A., Mainhard, M. T., Meijer, P. C., Pilot, A., Brekelmans, M. (2012). Master's thesis supervision: Relations between perceptions of the supervisor-student relationship, final grade, perceived supervisor contribution to learning and student satisfaction. Studies in Higher Education. 37(8), pp. 925-939.

https://doi.org/10.1080/03075079.2011.556717

Demaris, M. C., Kritsonis, W. A. (2008). The classroom: Exploring its effects on student persistence and satisfaction. Focus on Colleges, Universities, and Schools. 2(1), pp. 1-9. [Online]. Available from: http://www.nationalforum.com/Electronic\%20Journal\%20Volumes/Demaris,\%20Michalyn\%20The\%20Classroom.pdf [Accessed: 11th May 2017]

Denson, N., Loveday, T., Dalton, H. (2010). Student evaluation of courses: what predicts satisfaction? Higher Education Research \& Development. 29(4), pp. 339-356.

https://doi.org/10.1080/07294360903394466

DeShields Jr, O. W., Kara, A., Kaynak, E. (2005). Determinants of business student satisfaction and retention in higher education: applying Herzberg's two-factor theory. International Journal of Educational Management. 19(2), pp. 128-139. https://doi.org/10.1108/09513540510582426

Douglas, J., Douglas, A., Barnes, B. (2006). Measuring student satisfaction at a UK university. Quality Assurance in Education. 14(3), pp. 251-267. https://doi.org/10.1108/09684880610678568

Elliott, K. M., Healy, M. A. (2001). Key factors influencing student satisfaction related to recruitment and retention. Journal of Marketing for Higher Education. 10(4), pp. 1-11.

https://doi.org/10.1300/J050v10n04_01

Elliott, K. M., Shin, D. (2002). Student satisfaction: An alternative approach to assessing this important concept. Journal of Higher Education Policy and Management. 24(2), pp. 197-209. https://doi.org/10.1080/1360080022000013518

Fu, V. K. (1999). Estimating generalized ordered logit models. Stata Technical Bulletin. 8(44), pp. 27-30. [Online]. Available from: http://stata-press. com/journals/stbcontents/stb44.pdf [Accessed: 11th May 2017]

Gibson, A. (2010). Measuring business student satisfaction: A review and summary of the major predictors. Journal of Higher Education Policy and Management. 32(3), pp. 251-259.

https://oi.org/10.1080/13600801003743349

Giner, G. R., Rillo, A. P. (2015). Structural equation modeling of co-creation and its influence on the student's satisfaction and loyalty towards university. Journal of Computational and Applied Mathematics. 291, pp. 257-263. https://doi.org/10.1016/j.cam.2015.02.044

Ginsburg, M. B. (1991). Understanding Educational Reform in Global Context: Economy, Ideology, and the State. Taylor \& Francis.

Grace, B. Y., Kim, J.-H. (2008). Testing the mediating effect of the quality of college life in the student satisfaction and student loyalty relationship. Applied Research in Quality of Life. 3(1), pp. 1-21. https://doi.org/10.1007/s11482-008-9044-8 
Guo, W. W. (2010). Incorporating statistical and neural network approaches for student course satisfaction analysis and prediction. Expert Systems with Applications. 37(4), pp. 3358-3365.

https://doi.org/10.1016/j.eswa.2009.10.014

Harman, G. (2003). PhD student satisfaction with course experience and supervision in two Australian research-intensive universities. Prometheus. 21(3), pp. 312-333. https://doi.org/10.1080/0810902032000113460

Helgesen, Ø., Nesset, E. (2007). Images, satisfaction and antecedents: Drivers of student loyalty? A case study of a Norwegian university college. Corporate Reputation Review. 10(1), pp. 38-59. https://doi.org/10.1057/palgrave.crr.1550037

Hill, F. M. (1995). Managing service quality in higher education: the role of the student as primary consumer. Quality Assurance in Education. 3(3), pp. 10-21. https://doi.org/10.1108/09684889510093497

Hill, Y., Lomas, L., MacGregor, J. (2003). Students' perceptions of quality in higher education. Quality Assurance in Education. 11(1), pp. 15-20. https://doi.org/10.1108/09684880310462047

Khosravi, A. A., Poushaneh, K., Roozegar, A., Sohrabifard, N. (2013). Determination of Factors Affecting Student Satisfaction of Islamic Azad University. Procedia-Social and Behavioral Sciences. 84, pp. 579-583. https://doi.org/10.1016/j.sbspro.2013.06.607

Long, J. S., Freese, J. (2006). Regression models for categorical dependent variables using Stata. Stata press.

Mai, L.-W. (2005). A comparative study between UK and US: The student satisfaction in higher education and its influential factors. Journal of Marketing Management. 21(7-8), pp. 859-878. https://doi.org/10.1362/026725705774538471

Marzo Navarro, M., Pedraja Iglesias, M., Rivera Torres, P. (2005). A new management element for universities: satisfaction with the offered courses. International Journal of Educational Management. 19(6), pp. 505-526. https://doi.org/10.1108/09513540510617454

Montanari, A., Viroli, C. (2010). A skew-normal factor model for the analysis of student satisfaction towards university courses. Journal of Applied Statistics. 37(3), pp. 473-487. https://doi.org/10.1080/02664760902736737

Munteanu, C., Ceobanu, C., Bobâlca, C., Anton, O. (2010). An analysis of customer satisfaction in a higher education context. International Journal of Public Sector Management. 23(2), pp. 124-140. https://doi.org/10.1108/09513551011022483

Negricea, C. I., Edu, T., Avram, E. M. (2014). Establishing Influence of Specific Academic Quality on Student Satisfaction. Procedia-Social and Behavioral Sciences. 116, pp. 4430-4435. https://doi.org/10.1016/j.sbspro.2014.01.961

Oldfield, B. M., Baron, S. (2000). Student perceptions of service quality in a UK university business and management faculty. Quality Assurance in Education. 8(2), pp. 85-95. https://doi.org/10.1108/09684880010325600

Petruzzellis, L., D’Uggento, A. M., Romanazzi, S. (2006). Student satisfaction and quality of service in Italian universities. Managing Service Quality: An International Journal. 16(4), pp. 349-364. https://doi.org/10.1108/09604520610675694

Powers, D. A., Xie, Y. (2008). Statistical methods for categorical data analysis. Emerald Group Publishing.

Ravindran, S. D., Kalpana, M. (2012). Student's expectation, perception and satisfaction towards the management educational institutions. Procedia Economics and Finance. 2, pp. 401-410. https://doi.org/10.1016/S2212-5671(12)00102-5
Roman, I. (2014). Qualitative methods for determining students' satisfaction with teaching quality. Procedia-Social and Behavioral Sciences. 149, pp. $825-830$.

https://doi.org/10.1016/j.sbspro.2014.08.320

Sakthivel, P., Rajendran, G., Raju, R. (2005). TQM implementation and students' satisfaction of academic performance. The TQM magazine. 17(6), pp. 573-589. https://doi.org/10.1108/09544780510627660

Schertzer, C. B., Schertzer, S. M. (2004). Student satisfaction and retention: A conceptual model. Journal of Marketing for Higher Education. 14(1), pp. 79-91. https://doi.org/10.1300/J050v14n01_05

Sojkin, B., Bartkowiak, P., Skuza, A. (2012). Determinants of higher education choices and student satisfaction: the case of Poland. Higher Education. 63(5), pp. 565-581. https://doi.org/10.1007/s10734-011-9459-2

Sutton, K. L., Sankar, C. (2011). Student satisfaction with information provided by academic advisors. Journal of STEM Education: Innovations and Research. 12(7), pp. 71-85. [Online]. Available from: http://ojs.jstem.org/index.php?journal=JSTEMpage=articleop=viewpath $\% 5 \mathrm{~B} \% 5 \mathrm{D}=1734$ path $\% 5 \mathrm{~B} \% 5 \mathrm{D}=1404$ [Accessed: 11th May 2017]

Uysal, F. (2015). Evaluation of the factors that determine quality in graduate education: Application of a satisfaction benchmarking approach. Procedia-Social and Behavioral Sciences. 191, pp. 1034-1037. https://doi.org/10.1016/j.sbspro.2015.04.386

Wang, R., Tseng, M.-L. (2011). Evaluation of international student satisfaction using fuzzy importance-performance analysis. Procedia - Social and Behavioral Sciences. 25, pp. 438-446. https://doi.org/10.1016/j.sbspro.2012.02.055

Washington, S. P., Karlaftis, M. G., Mannering, F. L. (2010). Statistical and econometric methods for transportation data analysis. CRC Press.

Wilkins, S., Stephens Balakrishnan, M. (2013). Assessing student satisfaction in transnational higher education. International Journal of Educational Management. 27(2), pp. 143-156. https://doi.org/10.1108/09513541311297568

Wilkins, S., Stephens Balakrishnan, M., Huisman, J. (2012). Student satisfaction and student perceptions of quality at international branch campuses in the United Arab Emirates. Journal of Higher Education Policy and Management. 34(5), pp. 543-556. https://doi.org/10.1080/1360080X.2012.716003

Williams, R. (2006). Generalized ordered logit/partial proportional odds models for ordinal dependent variables. Stata Journal. 6(1), pp. 58-82. [Online]. Available from: http://www.stata-journal.com/sjpdf.html?articlenum=st0097 [Accessed: 11th May 2017]

Williams, R. (2010). Fitting heterogeneous choice models with oglm. Stata Journal. 10(4), 540-567. [Online]. Available from: http://www.stata-journal.com/article.html?article=st0208 [Accessed: 11th May 2017]

Yamane, T. (1967). Elementary Sampling Theory. Prentice- Hall, Inc.

Yang, Z., Becerik-Gerber, B., Mino, L. (2013). A study on student perceptions of higher education classrooms: Impact of classroom attributes on student satisfaction and performance. Building and Environment. 70, pp. 171-188. https://doi.org/10.1016/j.buildenv.2013.08.030

Zhao, C. M., Golde, C. M., McCormick, A. C. (2007). More than a signature: How advisor choice and advisor behaviour affect doctoral student satisfaction. Journal of Further and Higher Education. 31(3), pp. 263-281. https://doi.org/10.1080/03098770701424983 
Appendix

\section{Original Questionnaire}

\section{Dear Graduate Students,}

This questionnaire mainly intends to examine graduate students' quality of service perception in Atatürk University. All data obtained from this questionnaire will be used for scientific purposes only. The success of this survey mainly depends on your sincere responses. Thank you for attention and participation in advance.

$\begin{array}{cl}\mathbf{1} & \text { Your gender } \\ \mathbf{2} & \text { Your marital status } \\ \mathbf{3} & \text { Your age } \\ \mathbf{4} & \text { Dou you receive any tuition fee? } \\ & \\ \mathbf{5} & \text { Your monthly individual income? } \\ \mathbf{6} & \text { Your monthly household income? } \\ \mathbf{8} & \text { Your undergraduate education (university)? } \\ \mathbf{9} & \text { Your undergraduate education (department)? } \\ \mathbf{1 0} & \text { Your graduate school? }\end{array}$

11 Time elapsed (in years) for graduate education?

12 Current status of graduate education?

13 Advisor's academic degree?

14 Time spent on advisor's meeting (in hours)

15

Academic Advisor Satisfaction

I have an efficient communication with my academic advisor.

My academic advisor shares his/her expectations with me.

My academic advisor always encourages me.

I can share my future expectations with my academic advisor.

My academic advisor shares his/her own schedule with me.

(1) Female
(2) Male
(1) Married
(2) Single
$\ldots$
(1) Yes
(2) No

................TL

.............TL

$\ldots$

(1) Health sciences

(2) Social sciences

(3) Applied sciences

(4) Educational sciences ...

\section{(1) Master-course}

(2) Master-thesis

(3) PhD-course

(4) $\mathrm{PhD}$-qualification

(5) $\mathrm{PhD}$-thesis

(1) Assistant Prof.

(2) Associate Prof.

(3) Full Professor

...

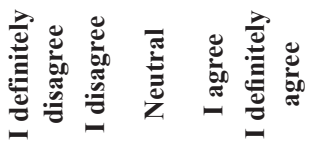
(1) (2) (3) (4) (5)
(1) (2) (3) (4) (5)
(1) (2) (3) (4) (5)
(1) (2) (3) (4) (5)
(1) (2) (3) (4) (5)
(1) (2) (3) (4) (5)
(1) (2) (3) (4) (5)
(1) (2) (3) (4) (5)

My academic advisor teaches me the ways of being suspicious, explorer and inspector for my academic career.

I am a keen admirer of my academic advisor.

My academic advisor provides assistance on orientation to academic life.
My academic advisor gives information about

My academic advisor provides assistance on the subject of my thesis.

My academic advisor encourages me on sharing my research findings with other researchers.

My academic advisor is intented to include

students to his/her own work/research.

My academic advisor closely monitors the way my work is going.

My academic advisor evaluates my draft papers

and shares his/her comments.

My academic advisor encourages me to involve in academic life.

My academic advisor follows contemporary trends in his/her research area.

I am always informed about my academic advisor's future projects.

I am generally satisfied with my academic advisor's guidance.

16

Satisfaction with Physical Facilities

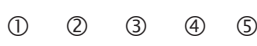

(1) (2) (3) (4) (5)

(1) (2) (3) (4) (5)

(1) (2) (3) (4) (5)

(1) (2) (3) (4) (5)

(1) (2) (3) (4) (5)

(1) (2) (3) (4) (5)

(1) (2) (3) (4) (5)

(1) (2) (3) (4) (5)

(1) (2) (3) (4) (5)

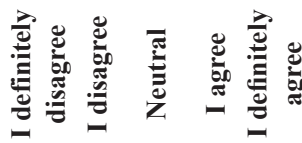

The number of classrooms is sufficient for efficient graduate education.

There are modern educational tools and

equipments in the graduate education classrooms.

There is a sufficient place of studying for graduate students.

The number of laboratories and computers is sufficient for efficient graduate education.

I am generally satisfied with physical facilities

for my graduate education.

17

Satisfaction with Academic Staff

(1) (2) (3) (4) (5)

(1) (2) (3) (4) (5)

(1) (2) (3) (4) (5)

(1) (2) (3) (4) (5)

(1) (2) (3) (4) (5)

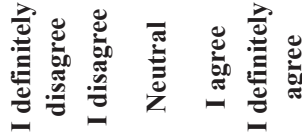

They are well-educated in their research area.

They teach the course in a clear and

understandable way.

They encourage students to be involved in the course subject.

They are open to any criticism.

They know how to draw attention to the class

They encourage students to work hard and a continuous research.

They are behind the promise they give about the lesson.

They teach their course with ambition.

They are intended to present the latest developments about the subject.

They encourage students about exams.

I am generally satisfied with academic staff.
(1) (2) (3) (4) (5)

(1) (2) (3) (4) (5)

(1) (2) (3) (4) (5)

(1) (2) (3) (4) (5)

(1) (2) (3) (4) (5)

(1) (2) (3) (4) (5)

(1) (2) (3) (4) (5)

(1) (2) (3) (4) (5)

(1) (2) (3) (4) (5)

(1) (2) (3) (4) (5)

(1) (2) (3) (4) (5) course outline 
Graduate school show sincere desire to solve students' problems.

(1) (2) (3) (4) (5)

Graduate school staff are honest towards students.

(1) (2) (3) (4) (5)

Graduate school staff are respectful to students.

Graduate school staff respond immediately to the student's requests.

Graduate school staff try to understand the

student's expectations.

(1) (2) (3) (4) (5)

(1) (2) (3) (4) (5)

(1) (2) (3) (4) (5)

Graduate school staff have enough knowledge to answer questions.

Graduate school staff are in a friendly and warm manner.

(1) (2) (3) (4) (5)

(1) (2) (3) (4) (5)

I am generally satisfied with graduate school services.

19

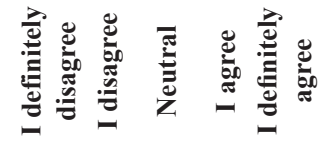

This university has always made a good impression on me.

The image of this university is better than the images of other universities.

(1) (2) (3) (4) (5)

(1) (2) (3) (4) (5)

This university has an important share in Turkey in terms of academic education.

(1) (2) (3) (4) (5)

I would recommend this university to others.

(1) (2) (3) (4) (5)

I feel a loyalty to my university.

(1) (2) (3) (4) (5)

I am proud of my university

(1) (2) (3) (4) (5) 